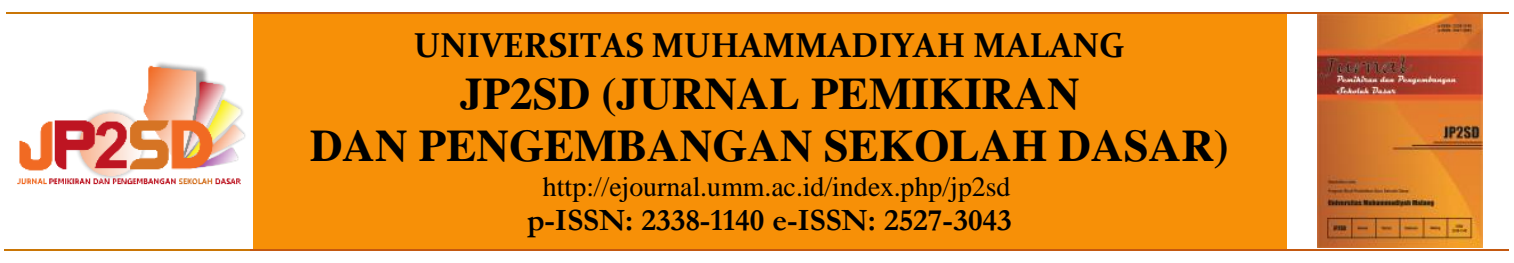

\title{
Pengaruh Media Puzzle Terhadap Hasil Belajar Aksara Jawa di Sekolah Dasar
}

\author{
Leny Suryaning Astutik $^{\text {a1 }}$, Ulva Listya Agustin $^{\text {b2 }}$, Beti Istanti Suwandayani ${ }^{\mathrm{c} 3}$ \\ ${ }^{a}$ Pendidikan Dasar, Universitas Negeri Malang, Indonesia \\ ${ }^{\mathrm{b}}$ Pendidikan Guru Sekolah Dasar, Universitas Muhammadiyah Malang, Indonesia \\ ${ }^{\mathrm{c}}$ Pendidikan Guru Sekolah Dasar, Universitas Muhammadiyah Malang, Indonesia \\ ${ }^{1}$ lennyshadenley@gmail.com, ${ }^{2}$ vhatyaagustin@gmail.com, ${ }^{3}$ beti@umm.ac.id
}

\begin{tabular}{ll}
\hline INFORMASI ARTIKEL \\
\hline Riwayat: \\
Diterima & 6 Maret \\
& 2020 \\
Revisi & 7 April \\
& 2020 \\
Dipublikasikan & 27 April \\
& 2020
\end{tabular}

Kata kunci:

Media, Bahasa Jawa, Aksara Jawa, Puzzle, Hasil Belajar

\begin{abstract}
ABSTRAK
Implementasi pembelajaran menggunakan media sudah seharusnya dijadikan salah satu solusi untuk mengatasi hasil belajar siswa yang rendah. Media konkret seperti Puzzle merupakan saran pendukung dalam kegiatan pembelajaran agar tujuan pembelajaran tercapai dan hasil belajar maksimal. Puzzle merupakan media konkret dimana media dapat diamati dan dirasakan langsung keberadaannya. Berdasarkan hasil observasi keadaan di SDN 1 Sukorejo 1 Blitar menunjukkan bahwa hasil belajar siswa mata pelajaran Bahasa Jawa khusunya materi aksara Jawa siswa masih kesulitan dalam membedakan bentuk aksara dan cara penulisannya. Penggunaan media mengenal dan membaca aksara Jawa sangat dibutuhkan oleh siswa supaya dapat berinteraksi langsung dengan media pembelajaran yang mengarah pada hasil belajar yang maksimal. Upaya ini diharapkan siswa dapat secara optimal menyerap materi Bahasa Jawa khususnya pada materi aksara Jawa. Penelitian ini bertujuan untuk mengetahui pengaruh penggunaan media Puzzle terhadap hasil belajar aksara Jawa siswa kelas III SD. Jenis penelitian yang digunakan adalah Quasi eksperimen dengan desain One Group Pretest-Posttest Design. Sampel dalam penelitian ini adalah siswa kelas III SDN Sukorejo 1 Blitar yang terdiri dari 30 siswa. Instrumen yang digunakan pada peneltiian ini adalah menggunakan soal tes. Analisis data menggunakan SPSS 21 for Windows. Hasil data menujukkan rata-rata pretest sebesar 52.7 dan posttest sebesar 83.2. Sedangkan hasil uji hipotesis menggunakan Paired
\end{abstract}


Sampel T-Test memperoleh thitung 26.339 sedangkan ttabel dengan $\mathrm{dk}=30-1=29$ dan taraf signifikan $(\alpha)=$ 0,05 adalah 2.045. Hasil akhir menunjukan thitung $\geq$ ttabel atau 26,339 $\geq 2,045$ yang berarti terdapat pengaruh yang signifikan pada penerapan media Puzzle terhadap hasil belajar aksara Jawa pada siswa kelas III SDN Sukorejo 1 Blitar.

\begin{tabular}{l}
\hline Keywords: \\
Media, Javanese \\
Language, Javanese Script, \\
Puzzle, Learning \\
Outcomes.
\end{tabular}

\section{ABSTRACT}

Implementation of learning using media that has been used One solution to overcome student learning outcomes are low. Concrete media such as Puzzles are supporting suggestions in learning activities so that learning objectives and learning outcomes are maximized. Puzzles are concrete media in which the media can be seen and accepted immediately. Based on observations of the situation at SDN 1 Sukorejo 1 Blitar, it showed students' learning outcomes in Javanese, especially Javanese characters, and it was still difficult for students to distinguish between the

Copyright (C) 2020, Leny Suryaning Astutik, dkk. This is an open access article under the CC-BY-SA license forms of writing and the way they were written. The use of media that are familiar with and read Javanesse script is very much needed by students who can be used directly with learning media aimed at maximum learning outcomes. This effort is expected that students can optimize the Javanese language material specifically on Javanese script material. Puzzles This study discusses the use of media Puzzles on learning outcomes of Javanese alphabet students in grade III elementary school. This type of research is a Quasi experiment with One Group Pretest-Posttest Design. The sample in this study was grade III students of SDN Sukorejo 1 Blitar consisting of 30 students. The instrument used in this study used test questions. Data analysis using SPSS 21 for Windows. The results of the data showed an average pretest of 52.7 and posttest of 83.2. While the results of hypothesis testing using Paired Sample T-Test were accepted thitung 26.333 while ttable with $\mathrm{dk}=30-1=29$ and the significant level $(\alpha)=0.05$ was 2.045 . The final results show thitung $\geq$ ttable or $26,339 \geq 2,045$ which means it has a significant influence on the media of applying Puzzles to the learning outcomes of Javanese script in grade III students of SDN Sukorejo 1 Blitar.

How to cite: Leny Suryaning Astutik, dkk. (2020). Pengaruh Media Puzzle Terhadap Hasil Belajar Aksara Jawa di Sekolah Dasar. Jurnal Pemikiran dan Pengembangan Sekolah Dasar, Vol 8 No 1, 79-87. doi: https://doi.org/ 10.22219/jp2sd.v8i1.12413 


\section{PENDAHULUAN}

Bahasa Jawa adalah salah satu mata pelajaran yang ada di SD. Mata pelajaran bahasa Jawa memuat pembelajaran terkait bahasa, sastra dan budaya Jawa (Arafik \& Rumidjan, 2017; Wibawa, 2013). Bahasa Jawa merupakan salah satu bahasa daerah. Keberadaan Bahasa Jawa di zaman globalisasi dan abad 21 sudah mulai ditinggalkan dan dilupakan oleh generasi penerus bangsa (Susetyo et al., 2014). Teknologi yang sangat canggih dan serba cepat saat ini, memberikan dampak dalam penggunaan bahasa. Bahasa daerah sangat bermanfaat guna meneruskan kearifan lokal. Generasi bangsa dengan budaya ketimuran harusnya melestarikan budaya tersebut (Yuhana \& Kuswardayan, 2013). Bahasa daerah yang menjadi icon atau lambing dari identitas daerah menjadi hal penting dalam penghubung komunikasi keluarga atau masyarakat daerah (Nurhasanah et al., 2016). Hal ini dibuktikan dengan salah satunya yaitu banyak generasi muda tidak bisa membaca aksara Jawa yang baik dan benar. Berdasarkan analisis kebutuhan dan observasi di SDN 1 Sukorejo Blitar diperoleh data bahwa nilai-nilai pada mata pelajaran Bahasa Jawa banyak yang belum memenui standart kelulusan. Selain itu sarana dan prasarana terkait mata pelajaran Bahasa Jawa juga tidak maksimal karena hanya ada gambar di dinding kelas. Kondisi seperti ini menyebabkan hasil belajar siswa rendah.

Hasil belajar adalah salah satu hubungan timbal balik siswa ketika telah selesai menyelesaikan sejumlah materi pembelajaran dalam bentuk nilai (Astuti, 2017; Astutik, 2019; Hamdu \& Agustina, 2011; Harahap, 2012; Sahara, 2015). Hasil belajar adalah pernyataan luas tentang apa yang dicapai dan dinilai pada akhir mata pelajaran (Harden, 2002). Hasil belajar memiliki lima komponen diataranya ada lima kategori hasil pembelajaran: (a) keterampilan intelektual, (b) informasi verbal, (c) strategi kognitif, (d) sikap, dan (e) keterampilan motorik (Gagne, 1984). Hasil belajar juga dipengaruhi oleh beberapa faktor internal (diri sendiri) dan faktor eksternal (alam, sarana, prasarana), faktor masyarakat, faktor keluarga, dan faktor psikologis (Hendikawati, 2011; Kristin, 2016; Kurniawan et al., 2017; Lestari et al., 2017; Mappeasse, 2009; Rijal \& Bachtiar, 2015). Salah satu contoh faktor yang mempengaruhi hasil belajar untuk sarana prasarana salah satunya adalah penggunaan media. Penggunaan media yang tepat akan meningkatkan hasil belajar siswa.

Media pembelajaran adalah alat atau perantara (Annisah, 2017; Arsyad, 2011; Mustaqim, 2016) yang berguna mempermudah penyampaian informasi dan memiliki manfaat mengatasi keterbatasan ruang, waktu, dan indera (Astutik, 2019). Media pembelajaran merupakan peranan yang tidak dapat dipisahkan dalam pembelajaran. Media pembelajaran berguana untuk mengirim pesan dari pengirim kepada penerima (Arsyad, 2011; Sri, 2008). Media pembelajaran bersifat konkret (dapat diraba / disentuh) sangat penting (Destrinelli et al., 2018; Santiani et al., 2017) diberikan kepada siswa Sekolah Dasar kelas III. Karena pada tahap ini memudahkan siswa untuk mengkonkretkan materi yang bersifat abstrak. Media Puzzle memiliki manfaat diantaranya dapat mengasah otak, melatih nalar, kesabaran, pengetahuan, melatih koordinasi tangan dan mata.

Kelebihan media puzzle yaitu bersifat konkret (Anjani, 2019; Hendarwati, 2014; Murbarani, 2014; Nisa'Enha, 2015; Winanti, 2015; Wulandari \& Herawanto, n.d.) sehingga dapat menarik minat dan perhatian siswa, meningkatkan hasil belajar serta dapat mengatasi keterbatasan ruang dan waktu (Marwanto et al., 2014), (Husna et al., 2017). Kelemahan media puzzle yaitu kurang maksimal bila diterapkan dalam kelompok besar, tata cara penyampian pembelajaran menggunakan Puzzle, lebih menekankan indera penglihatan, serta media Puzzle yang terlalu kompleks kurang efektif untuk pembelajaran 
(Basuni, n.d.; Cahyadi \& Hernita, 2016; Murbarani, 2014; Permata et al., 2017; Wulandari \& Herawanto, n.d.).

Penelitian ini bertujuan untuk mengetahui pengaruh media Puzzle dengan tambahan fitur audio untuk meningkatkan hasil belajar siswa kelas III materi aksara Jawa. Media ini diharapkan mampu meningkatkan minat dan kemampuan siswa dalam mengenal dan membaca aksara Jawa, sehingga siswa mendapatkan hasil yang maksimal. Media Puzzle ini akan membantu siswa untuk lebih mudah mengenal huruf aksara Jawa dan juga cara membaca.

Meskipun berbeda materi, penelitian ini sejalan dengan penelitian terdahulu dengan hasil belajar kognitif siswa kelas IV pada materi sistem ekskresi dengan media Puzzle mengalami peningkatan terutama pada perilaku siswa kearah yang lebih baik . Berdasarkan hal tersebut, dapat disimpulkan bahwa penelitian ini penting dilakukan untuk mengetahui pengaruh media Puzzle pada materi aksara Jawa siswa kelas III Sekolah Dasar (Ina et al., 2017).

\section{METODE}

Jenis penelitian ini adalah penelitian eksperimen. Desain penelitian yang digunakan yaitu One Group Pretest Posttest Design.

\section{$\mathrm{O}_{1} \mathrm{X} \mathrm{O}_{2}$}

\section{Gambar 1. Desain one group pretest posttest design}

Keterangan:

$\mathrm{O} 1$ : nilai pretest

$\mathrm{O} 2$ : nilai posttest

X : Perlakuan (treatment) (Antika \& Suprianto, 2016).

Penelitian ini tidak menggunakan kelas kontrol karena hanya menggunakan satu kelas sebagai kelas eksperimen. Populasi dalam penelitian ini adalah siswa di SDN 1 Sukorejo Blitar. Sampel mengambil total sampling yang berjumlah 30 siswa kelas III Sekolah Dasar. Analisis data yang diperoleh nantinya akan digunakan analisis secara deskriptif dan inferensial.

\section{HASIL DAN PEMBAHASAN}

Media pembelajaran merupakan alat bantu mengajar bagi guru untuk menyampaikan pengajaran kepada peserta didik. Dengan penggunaan media anak lebih termotivasi untuk belajar (Handhika, 2012; Indaryati \& Jailani, 2015; Nugroho et al., 2013; Sukiyasa \& Sukoco, 2013). Media pembelajaran harus difungsikan untuk meningkatkan kulaitas belajar mengajar. Media pembelajaran ini digunakan dalam belajar mengajar untuk memucahkan pencapaian tujuan-tujuan pembelajaran yang telah dirumuskan.

Berdasarkan hasil penelitian yang telah dilakukan di SDN 1 Sukorejo Blitar diperoleh data yang didapatkan dari instrumen tes. Instrumen tes merupakan alat yang digunakan untuk melakukan serangkaian ujicoba atau tes dengan butir-butir pernatanyaan (Kuncahyono, 2019). Intrumen tes dibagi menjadi dua yaitu pretest dan posttest. 
Berdasarkan hasil data tersebut dapat diketahui hasil belajar siswa di SDN 1 Sukorejo Blitar.

a. Data pretest hasil belajar materi aksara Jawa kelas III di SDN 1 Sukorejo Blitar. Secara kuantitatif skor nilai hasil belajar aksara Jawa pada pretest dapat dilihat pada tabel 1.

Tabel 1. Skor pretest hasil belajar siswa SDN 1 Sukorejo Blitar

\begin{tabular}{cc}
\hline Keterangan & Nilai \\
\hline Jumlah Siswa & 30 \\
Nilai Ideal & 100 \\
Nilai Maksimal & 37.5 \\
Nilai Minimal & 67.5 \\
\hline Nilai Rata-Rata & 52.7 \\
\hline
\end{tabular}

Berdasarkan tabel 1 diatas menunjukkan hasil pretest materi aksara Jawa di kelas III SDN 1 Sukorejo Blitar menunjukkan rata-rata (mean) sebesar 52.7 dari skor ideal sebesar 100. Skor maksimum pada pretest sebesar 67.5 dan skor minimum yang didapatkan siswa sebesar 37.5. Hal ini menunjukkan bahwa rata-rata skor pretest tergolong rendah. Pretest ini dilakukan untuk menguji tingkatan pengetahuan peserta didik terhadap materi yang akan disampaikan.

Manfaat pretest ini untuk mengetahui kemampual awal peserta didik mengenai pelajaran yang disampaikan. Skor pretest rendah dikarenakan kurangnya antusias siswa (Kristin, 2016b; Natalia, 2015; Rahayu, 2009; Rosidah, 2017) dalam mempelajari aksara Jawa dan terbatasnya media atau sarana prasarana yang menunjang pembelajaran. Apabila skor hasil belajar siswa dikelompokkan menjadi kriteria maka dapat disajikan pada tabel 2 .

Tabel 2. Statistik frekuensi pretest siswa SDN 1 Sukorejo Blitar

\begin{tabular}{cccc}
\hline No & Skor & Kriteria & Frekuensi \\
\hline 1. & $0-40$ & Sangat Rendah & 5 \\
\hline 2. & $41-55$ & Rendah & 13 \\
\hline 3. & $56-75$ & Sedang & 12 \\
\hline 4. & $76-85$ & Tinggi & 0 \\
\hline 5. & $86-100$ & Sangat Tinggi & 0 \\
\hline
\end{tabular}

(Olahan Peneliti, 2020).

Berdasarkan tabel 2 diperoleh data dari 30 siswa terdapat 5 siswa berada pada kriteria sangat rendah, 13 siswa pada kriteria rendah, 12 siswa berada pada kriteria sedang dan tidak ada siswa yang berada pada kriteria tinggi atau sangat tinggi. Berdasarkan data pretest hasil belajar tersebut dapat diambil kesimpulan bahwa siswa kelas III di SDN 1 Sukorejo Blitar tidak mencapai Kriteria Ketuntasan Minimal (KKM) 75.

b. Data posttest hasil belajar materi aksara Jawa kelas III di SDN 1 Sukorejo Blitar

Secara langsung kelas pada penelitian diberikan perlakuan. Perlakuan berupa media puzzle sebagai alat bantu pembelajaran sehingga dapat dilihat pengaruh keberadaan puzzle dalam pembelajaran. Adapun hasil skor secara kuantitatif pada posttest dapat dilihat pada tabel 3 .

Tabel 3. Skor posttest hasil belajar siswa SDN 1 Sukorejo Blitar

\begin{tabular}{lc}
\hline \multicolumn{1}{c}{ Keterangan } & Nilai \\
\hline Jumlah Siswa & 30 \\
Nilai Ideal & 100 \\
\hline Nilai Maksimal & 75 \\
\hline Nilai Minimal & 92.5 \\
\hline Nilai Rata-Rata & 83.2 \\
\hline
\end{tabular}


Berdasarkan tabel 3 diatas menunjukkan hasil posttest materi aksara Jawa di kelas III SDN 1 Sukorejo Blitar menunjukkan rata-rata (mean) sebesar 83.2 dari skor ideal sebesar 100. Skor maksimum pada posttest sebesar 92.5 dan skor minimum yang didapatkan siswa sebesar 75. Hal ini menunjukkan bahwa rata-rata skor posttest tergolong tingi.

Tabel 4. Statistik frekuensi posttest siswa SDN 1 Sukorejo Blitar

\begin{tabular}{cccc}
\hline No & Skor & Kriteria & Frekuensi \\
\hline 1. & $0-40$ & Sangat Rendah & 0 \\
2. & $41-55$ & Rendah & 0 \\
3. & $56-75$ & Sedang & 3 \\
4. & $76-85$ & Tinggi & 18 \\
5. & $86-100$ & Sangat Tinggi & 9 \\
\hline
\end{tabular}

Berdasarkan tabel 4 diperoleh data dari 30 siswa terdapat 3 siswa berada pada kriteria sedang, 18 siswa pada sedang, 9 siswa berada pada kriteria sangat tinggi dan tidak ada siswa yang berada pada kriteria rendah atau sangat rendah. Berdasarkan data posttest hasil belajar tersebut dapat diambil kesimpulan bahwa siswa kelas III di SDN 1 Sukorejo Blitar telah mencapai Kriteria Ketuntasan Minimal (KKM) 75.

\section{c. Pengaruh Penggunaan Media Puzzle Terhadap Hasil Belajar Materi Aksara Jawa Siswa Kelas III SDN 1 Sukorejo Blitar}

Hipotesis penelitian ini adalah "penggunaan Media Puzzle Terhadap Hasil Belajar Materi Aksara Jawa Siswa Kelas III SDN 1 Sukorejo Blitar". Maka langkah yang akan digunakan untuk mengolah data menggunakan uji-t. Hasil analisis serta perhitungan dengan prosedur yang telah ditentukan maka hasil dapat dilihat pada tabel 5.

Tabel 5. Hasil Pengolahan Data Berdasarkan Hasil Belajar Aksara Jawa

\begin{tabular}{lcc}
\hline \multirow{2}{*}{ Keterangan } & \multicolumn{2}{c}{ Hasil } \\
\cline { 2 - 3 } & Pretest & Posttest \\
\hline Rata-Rata & 52.67 & 83.17 \\
Standar Deviasi & 8.634 & 5.290 \\
Uji Normalitas & .844 & .734 \\
& thitung & ttabel \\
Uji Hipotesis & 26.339 & 2.045 \\
\hline
\end{tabular}

Berdasarkan hasil pengolaha data test pada siswa kelas III di SDN 1 Sukorejo Blitar pada tabel 5 diperoleh hasil (1), Nilai rata-rata pretest siswa sebesar 52.67 dan ratarata posttest siswa sebesar 83.17 atau dapat dikatakan bahwa nilai mengalami peningkatan sebesar 30.48. Pada uji normalitas pretest diperoleh .844 dan pada posttest .734. Pada uji hipotesis (t) menggunakan Paired Sampel T-Test memperoleh thitung 26.339 sedangkan ttabel dengan $\mathrm{dk}=30-1=29$ dan taraf signifikan $(\alpha)=0,05$ adalah 2.045. Hasil akhir menunjukan thitung $\geq$ ttabel atau $26,339 \geq 2,045$ yang berarti terdapat pengaruh yang signifikan pada penerapan media Puzzle terhadap hasil belajar aksara Jawa pada siswa kelas III SDN Sukorejo 1 Blitar).

\section{SIMPULAN}

Implementasi pembelajaran media Puzzle membantu siswa dalam meningkatkan hasil belajar khusunya materi aksara Jawa. Berdasarkan hasil penelitian dapat disimpulkan bahwa terdapat pengaruh penggunaan media Puzzle terhadap hasil belajar khusunya materi aksara Jawa di Sekolah 1 Sukorejo Blitar. Hal ini disimpulkan 
berdasarkan data karena terdapat perbedaan rata-rata antara nilai pretest 52.3 dan pada posttest adalah 83.2. Hasil akhir menunjukan thitung $\geq$ ttabel atau 26,339 $\geq 2,045$ yang berarti terdapat pengaruh yang signifikan pada penerapan media Puzzle terhadap hasil belajar aksara Jawa pada siswa kelas III SDN Sukorejo 1 Blitar.

\section{REFERENSI}

Anjani, R. D. (2019). Pembelajaran Kooperatif Tipe STAD Berbantu Media Puzzle untuk Meningkatkan Keaktifan Peserta Didik di Kelas XI Multimedia SMK Hidayatul Ummah Balongpanggang [PhD Thesis]. Universitas Muhammadiyah Gresik.

Annisah, S. (2017). Alat Peraga Pembelajaran Matematika. Tarbawiyah Jurnal Ilmiah Pendidikan, 11(01), 1-15.

Antika, Y., \& Suprianto, B. (2016). Pengembangan Media Pembelajaran Berbasis Prezi Sebagai Upaya Meningkatkan Hasil Belajar Siswa Kompetensi Dasar Aplikasi Rangkaian Op Amp Mata Pelajaran Rangkaian Elektronika Di Smk Negeri 2 Bojonegoro. Jurnal Pendidikan Teknik Elektro, 05(02), 493-497.

Arafik, M., \& Rumidjan, R. (2017). Profil pembelajaran unggah-ungguh bahasa Jawa di sekolah dasar. Sekolah Dasar: Kajian Teori Dan Praktik Pendidikan, 25(1), 5561.

Arsyad, A. (2011). Media pembelajaran. Jakarta: PT Raja Grafindo Persada.

Astuti, C. C. (2017). Analisis Korelasi untuk Mengetahui Keeratan Hubungan antara Keaktifan Mahasiswa dengan Hasil Belajar Akhir. JICTE (Journal of Information and Computer Technology Education), 1(1), 1-7.

Astutik, L. S. (2019). Pengaruh Media Laron ( Gamelan Saron ) Dengan Lagu Daerah Terhadap Hasil Belajar Untuk Anak. Jurnal Pemikiran Dan Pengembangan Sekolah Dasar, 7(April), 23-29.

Basuni, A. (n.d.). Efektivitas penggunaan media puzzle huruf hijaiyah dalam upaya meningkatkan pemahaman siswa terhadap materi baca tulis alqur'an di SDN Periuk 1 Kota Tangerang.

Cahyadi, F., \& Hernita, M. I. (2016). Peningkatan keaktifan dan kemampuan berhitung melalui media puzzle pada anak. PAUDIA: Jurnal Penelitian Dalam Bidang Pendidikan Anak Usia Dini, 5(1).

Destrinelli, D., Hayati, D. K., \& Sawinty, E. (2018). Pengembangan Media Konkret Pada Pembelajaran Tema Lingkungan Kelas III Sekolah Dasar. Jurnal Gentala Pendidikan Dasar, 3(2), 313-333.

Gagne, R. (1984). Learning outcomes and their effects. The American Psychologist, 39(4), 377-385.

Hamdu, G., \& Agustina, L. (2011). Pengaruh Motivasi Belajar Siswa Terhadap Pestasi Belajar IPA Di SMP Negeri 25 Batam. Jurnal Penelitian Pendidikan, 12(1), 8186.

Handhika, J. (2012). Efektivitas media pembelajaran IM3 ditinjau dari motivasi belajar. Jurnal Pendidikan IPA Indonesia, 1(2).

Harahap, F. (2012). Pengaruh Model Pembelajaran Inquiry Training Terhadap Hasil Belajar Siswa Pada Materi Pokok Suhu Dan Pengukuran Kelas VII Semester I MTs N 2 Medan TP 2012/2013 [PhD Thesis]. UNIMED.

Harden, R. M. (2002). Learning outcomes and instructional objectives: Is there a difference? Medical 24(2), Teacher, 151-155. https://doi.org/10.1080/0142159022020687 
Hendarwati, E. (2014). Pemanfaatan Media Dalam Pembelajaran Pengetahuan Sosial Di Taman Kanak-Kanak. Jurnal Pedagogi, 1(1).

Hendikawati, P. (2011). Analisis faktor yang mempengaruhi indeks prestasi mahasiswa. Kreano, Jurnal Matematika Kreatif-Inovatif, 2(1), 27-35.

Husna, N., Sari, S. A., \& Halim, A. (2017). Pengembangan Media Puzzle Materi Pencemaran Lingkungan di SMP Negeri 4 Banda Aceh. Jurnal Pendidikan Sains Indonesia (Indonesian Journal of Science Education), 5(1), 66-71.

Ina, K., Nurwahyunani, A., \& Dewi, E. R. S. (2017). Pengaruh Model Pembelajaran TGT Menggunakan Media Puzzle Terhadap Keaktifan Dan Hasil Belajar Kognitif Siswa Pada Materi Sistem Ekskresi. Bioma, 6(2), 78-92.

Indaryati, I., \& Jailani, J. (2015). Pengembangan media komik pembelajaran matematika meningkatkan motivasi dan prestasi belajar siswa kelas V. Jurnal Prima Edukasia, 3(1), 84-96.

Kristin, F. (2016). Analisis model pembelajaran discovery learning dalam meningkatkan hasil belajar siswa SD. Jurnal Pendidikan Dasar Perkhasa: Jurnal Penelitian Pendidikan Dasar, 2(1), 90-98.

Kuncahyono, K. (2019). PENGEMBANGAN INSTRUMEN E-TEST SEBAGAI INOVASI PENILAIAN BERBASIS ONLINE DI SEKOLAH DASAR kuncahyono | JINoP (Jurnal Inovasi Pembelajaran). http://202.52.52.22/index.php/jinop/article/view/7139/7441

Kurniawan, B., Wiharna, O., \& Permana, T. (2017). Studi Analisis Faktor-Faktor yang Mempengaruhi Hasil Belajar pada Mata Pelajaran Teknik Listrik Dasar Otomotif. Journal of Mechanical Engineering Education, 4(2), 156-162.

Lestari, I. A., Amir, H., \& Rohiat, S. (2017). Hubungan Persepsi Siswa Kelas X MIPA Di SMA Negeri Sekota Bengkulu Tahun Ajaran 2016/2017 Tentang Variasi Gaya Mengajar Guru Dengan Hasil Belajar Kimia. Alotrop, 1(2).

Mappeasse, Muh. Y. (2009). Pengaruh Cara dan Motivasi Belajar Terhadap Hasil Belajar Programmable Logic Controller (PLC ) Siswa Kelas III Jurusan Listrik SMK Negeri 5 Makassar. Jurnal Medtek, 1(2), 1-6.

Marwanto, R., Seribulan, M. N. M., \& Isfaeni, H. (2014). Pengaruh Strategi Pembelajaran Assurance Relevance Interest Assessment Satisfaction (Puzzle vs Video) terhadap Hasil Belajar Kognitif Siswa tentang Ekosistem di MAN 8 Jakarta. BIOSFER, 7(2), 41-46. https://doi.org/10.1017/CBO9781107415324.004

Murbarani, A. (2014). Pengembangan Media Puzzle Elektronik tentang Rangka Tubuh Manusia pada Mata Pelajaran IPA untuk Meningkatkan Hasil Belajar Siswa Kelas IV di SDN Jombatan V Jombang. Jurnal Mahasiswa Teknologi Pendidikan, 5(3).

Mustaqim, I. (2016). Pemanfaatan Augmented Reality sebagai media pembelajaran. Jurnal Pendidikan Teknologi Dan Kejuruan, 13(2), 174-183.

Nisa'Enha, H. (2015). Pengembangan Media Puzzle Pada Konsep Pengukuran Bangun Datar Terhadap Pemahaman Siswa Kelas IV MI Al Mufidah Wongsorejo Banyuwangi. Skripsi Tidak Diterbitkan.

Nugroho, A. P., Raharjo, T., \& Wahyuningsih, D. (2013). Pengembangan media pembelajaran Fisika menggunakan permainan ular tangga ditinjau dari motivasi belajar siswa kelas VIII Materi Gaya. Jurnal Pendidikan Fisika, 1(1), 11-18.

Nurhasanah, N., Wurianto, A. B., \& Arifin, B. (2016). Pengembangan media kijank (komik indonesia, jawa, dan aksara jawa) pembelajaran bahasa jawa kelas 5 sekolah dasar. Jurnal Pemikiran Dan Pengembangan Sekolah Dasar (JP2SD), 1(4), 267-273. 
Permata, K. K., Rustono, W. S., \& Lidinillah, D. A. M. (2017). Media Puzzle Berbasis Tangram dalam Pembelajaran IPS. Indonesian Journal of Primary Education, $1(1), 66-72$.

Rijal, S., \& Bachtiar, S. (2015). Hubungan antara Sikap, Kemandirian Belajar, dan Gaya Belajar dengan Hasil Belajar Kognitif Siswa. Jurnal Bioedukatika, 3(2), 15-20.

Sahara, L. (2015). Pengaruh Metode Pembelajaran Penemuan Terbimbing terhadap Hasil Belajar dan Aktivitas Siswa pada Materi Pokok Suhu dan Kalor di SMA Negeri 1 Limapuluh [PhD Thesis]. UNIMED.

Santiani, N. W., Sudana, D. N., \& Tastra, I. D. K. (2017). Pengaruh Model Pembelajaran Problem Based Learning Berbantuan Media Konkret Terhadap Hasil Belajar IPA Siswa Kelas V SD. MIMBAR PGSD Undiksha, 5(2).

Sri, A. (2008). Media pembelajaran. Surakarta: UPT UNS Press Universitas Sebelas Maret.

Sukiyasa, K., \& Sukoco, S. (2013). Pengaruh media animasi terhadap hasil belajar dan motivasi belajar siswa materi sistem kelistrikan otomotif. Jurnal Pendidikan Vokasi, 3(1).

Susetyo, DP. B., Widiyatmadi, HM. E., \& Sudiantara, Y. (2014). Self Concept Self Appreciation of Javanese People. Psikodimensia, 13(1), 47. https://doi.org/10.24167/psiko.v13i1.277

Wibawa, S. (2013). Mengukuhkan pembelajaran bahasa, sastra, dan budaya daerah sebagai muatan lokal. Konferensi Internasional Budaya Daerah III, 1-13.

Winanti, S. (2015). Pengembangan Media Puzzle Rantai Makanan untuk Mata Pelajaran Ilmu Pengetahuan Alam Sd. E-Jurnal Skripsi Program Studi Teknologi Pendidikan.

Wulandari, D. A., \& Herawanto, B. (n.d.). Penerapan Media Puzzle Kata Untuk Keterampilan Berbicara Kelas X SMAN 2 Jombang.

Yuhana, U. L., \& Kuswardayan, I. (2013). Aplikasi Belajar Menulis Aksara Jawa Menggunakan Android. Jurnal Teknik ITS, 2(1), A94-A98 